\title{
Determination of Lead(II) as Brillant Black BN Chelates in Water and Soil Samples After Separation- Preconcentration on Cellulose Nitrate Membrane Filter
}

\author{
Mustafa Soylak and Sevtap Yigit \\ Erciyes University, Faculty of Sciences, Department of Chemistry, \\ 38039, Kayseri, Turkey
}

\section{INTRODUCTION}

The main industrial activities, which includes agriculture, mining, and food processing, are one of the reasons for the high levels of trace elements, i.e., lead, in the environment (1-4). Lead is known to be toxic (5-7) and is also the most important/ubiquitous pollutant in food and natural water samples. Lead is a malleable metal previously used to improve the durability and luster of paint used in homes and on industrial structures, including pipe batteries, lines, and bridges (8). Lead at trace levels can damage the nervous system, the gastrointestinal track, and cause cancer in organs, i.e., the kidneys $(9,10)$. The accurate determination of lead in environmental samples using modern instrumental techniques is very important for environmental studies (11-13). However, metal concentrations in highly saline samples are often lower than the detection limits of the instrumental technique (14-18). To solve these kinds of problems, separation and enrichment procedures (19-25) are used, such as solid phase extraction, solvent extraction, cloud point extraction, microextraction, coprecipitation, and electroanalytical techniques.

Membrane filtration is also one of the simple and accurate separation-enrichment techniques (2629), and has been used for the preconcentration and separation of metal ions at trace levels in environ-

Corresponding author.

E-mail: soylak@erciyes.edu.tr

TelEFax: +90 3524374933

\section{ABSTRACT}

A membrane filtration procedure for the preconcentration and separation of $\mathrm{Pb}$ (II) at trace levels has been established. Cellulose nitrate membrane filters were used. The procedure is based on chelate formation of $\mathrm{Pb}$ (II) with Brillant Black $\mathrm{BN}$ and on the adsorption of the chelates on a cellulose nitrate membrane filter. The cellulose nitrate membrane was completely dissolved in $0.5 \mathrm{~mL}$ nitric acid and completed to $5 \mathrm{~mL}$ with water. Lead determinations were performed by flame atomic absorption spectrometry. Lead was quantitatively recovered at $\mathrm{pH} 7.0$ with 0.75 $\mathrm{mg}$ of Brillant Black BN at $4 \mathrm{~mL}$ $\mathrm{min}^{-1}$ flow rate. The detection limit for lead and the preconcentration factor were $1.5 \mu \mathrm{g} / \mathrm{L}$ and 50 , respectively. Validation of the method was checked by using certified reference materials SPSWW2 Wastewater Level 2 and GBW 07424 Soil. The method was applied to natural water samples for the determination of lead with satisfactory results.

mental samples prior to their instrumental detection.

In the present work, a separation-preconcentration procedure has been established using membrane filtration of trace levels of lead as Brillant Black BN chelates on a cellulose nitrate membrane filter for flame atomic absorption spectrometric determination. According to our literature survey, this procedure has never been published before.

\section{EXPERIMENTAL}

\section{Instrumentation}

A PerkinElmer® Model 3110 flame atomic absorption spectrometer, equipped with a hollow cathode lamp and an air/acetylene flame as the atomizer, was used for the measurements (PerkinElmer, Inc., Shelton, CT, USA). The equipment was used at conditions recommended by the manufacturer. The operating parameters are listed in Table I.

TABLE I

FAAS Operating Parameters for $\mathbf{P b}$ Determination

$\begin{array}{ll}\text { Wavelength } & 283.3 \mathrm{~nm} \\ \text { Slit Width } & 0.7 \mathrm{~nm} \\ \text { Lamp current } & 15 \mathrm{~mA}\end{array}$

A Sartorius PT-10 pH meter (Germany) with a glass electrode was used for adjustment of the $\mathrm{pH}$. Water was purified by reverse osmosis (18.2 M $\Omega \mathrm{cm}$, Millipore Corporation, USA) and used in the preparation of the solutions. An Erlenmeyer flask with a ground stopper was used for the membrane filtration procedure.

\section{Reagents and Solutions}

Membrane filters were purchased from Osmonics Inc. (Westborough, MA, USA). A 0.1\% (w/V) solution of Brillant Black BN (CAS No. 2519-30-4 solution (No: 211842, Sigma Aldrich Co., Milwaukee, WI, USA) was prepared daily in ethanol. The $\mathrm{pH}$ of the model solution was adjusted to $\mathrm{pH} 2$ with phosphate buffer, pH 4-6 with $\mathrm{CH}_{3} \mathrm{COO}^{-} / \mathrm{CH}_{3} \mathrm{COOH}$ buffers, 
pH 7 with phosphate buffer, and pH 8 with $\mathrm{NH}_{3} / \mathrm{NH}_{4}{ }^{+}$buffer.

The certified reference materials GBW 07424 Soil and SPS-WW2 Wastewater Level 2 were purchased from the National Research Center for Certified Reference Materials (Beijing, P.R. China) and from Spectrapure Standards AS (Oslo, Norway), respectively.

\section{Preconcentration Procedure}

A 25-mL portion of an aqueous solution containing $20 \mu \mathrm{g} \mathrm{Pb}(\mathrm{II})$ ions was placed in a glass beaker. Then $10 \mathrm{~mL}$ buffer solution and Brillant Black BN solution were added. After 10 minutes, lead-Brillant Black BN chelates were collected through a cellulose nitrate membrane filter of $0.45 \mu \mathrm{m}$ size and $47 \mathrm{~mm}$ diameter. The collection was performed very quickly by filtration under suction with an aspirator. Then the membrane was completely dissolved in $500 \mu \mathrm{L}$ concentrated nitric acid on a hot plate at $80{ }^{\circ} \mathrm{C}$. The solution was evaporated to dryness and the residue diluted to $5.0 \mathrm{~mL}$ with $1 \mathrm{M} \mathrm{HNO}_{3}$. Lead was determined by flame AAS.

\section{Application to Real Samples}

Soil samples were collected from the city center of Kayseri, Urgup, and Avanos regions of Turkey. The samples were dried at a temperature of $80{ }^{\circ} \mathrm{C}$ for 24 hours and homogenized by using an agate mortar and pestle.

A $0.5 \mathrm{~g}$ amount of GBW 07424 Soil certified reference material and a $1 \mathrm{~g}$ amount of each soil sample was digested with aqua regia (18 $\mathrm{mL}$ concentrated hydrochloric acid and $6 \mathrm{~mL}$ concentrated nitric acid) at room temperature, and heated to $150{ }^{\circ} \mathrm{C}$. After evolution of the $\mathrm{NO}_{2}$ fumes ceased, the mixture was evaporated to near dryness, mixed with $24 \mathrm{~mL}$ of aqua regia, then again evaporated to dryness. After evaporation, $10 \mathrm{~mL}$ distilled water was added and the sample mixed. The resulting mixture was filtered through a $589 / 3$ blue ribbon filter paper (B125 mm, Schleicher \& Schuell, Germany) and the filtrate diluted to $25 \mathrm{~mL}$ with distilled water. Then the procedure given in the "Preconcentration Procedure" section was applied. The final volume was completed to $5.0 \mathrm{~mL}$ with distilled water. The lead concentration in this solution was determined by FAAS.

A $4.0 \mathrm{~mL}$ amount of SPS-WW2 Wastewater Level 2 certified reference material or $100 \mathrm{~mL}$ amount of water samples was taken into a beaker, and the $\mathrm{pH}$ of the sample adjusted to $\mathrm{pH} 7.0$ with the buffer solution. Then the separation/preconcentration study developed above was performed. The concentration of lead in the final solution was determined by FAAS.

\section{RESULTS AND DISCUSSION}

\section{Influence of $\mathbf{p H}$}

The $\mathrm{pH}$ is an important parameter for the separation-preconcentration of metal ions as their chelates with ligands (30-33). The effect of $\mathrm{pH}$ on the retention of the $\mathrm{Pb}$ (II) ions as Brillant Black BN chelates on a cellulose nitrate membrane filter was investigated in the $\mathrm{pH}$ range of 2.0-8.0. The $\mathrm{pH}$ adjustments were done by using buffer solutions as listed in the "Experimental" section. The results in Figure 1 show that the recovery values were not quantitative in the range of $\mathrm{pH}$ 2.0-6.5. The quantitative recovery (>95\%) for $\mathrm{Pb}$ was found at the $\mathrm{pH}$ 7.0. All subsequent studies were carried out at $\mathrm{pH}$ 7.0.

\section{Effect of Amount of Brillant Black BM}

In various separation and preconcentration studies (34-39) it has been reported that complexation of metal ions with a suitable chelating agent improves the recoveries of the analyte ions. In our study, we examined the influence of different Brillant Black BN amounts on the recoveries of $\mathrm{Pb}$ (II) on the cellulose nitrate membrane filter while keeping other parameters constant. The results in Figure 2 show that the recoveries of $\mathrm{Pb}(\mathrm{II})$ ions were quantitative in the range of $0.5-2.0 \mathrm{mg}$ of Brillant Black BM. The addition of $0.2 \mathrm{mg}$ of Brillant Black BN solution was selected for this study.

\section{Effect of Flow Rate for Sample Solution}

The effect of sample flow rate on the recoveries of $\mathrm{Pb}$ (II) was studied in the $1.0-5.0 \mathrm{~mL} \mathrm{~min}^{-1}$

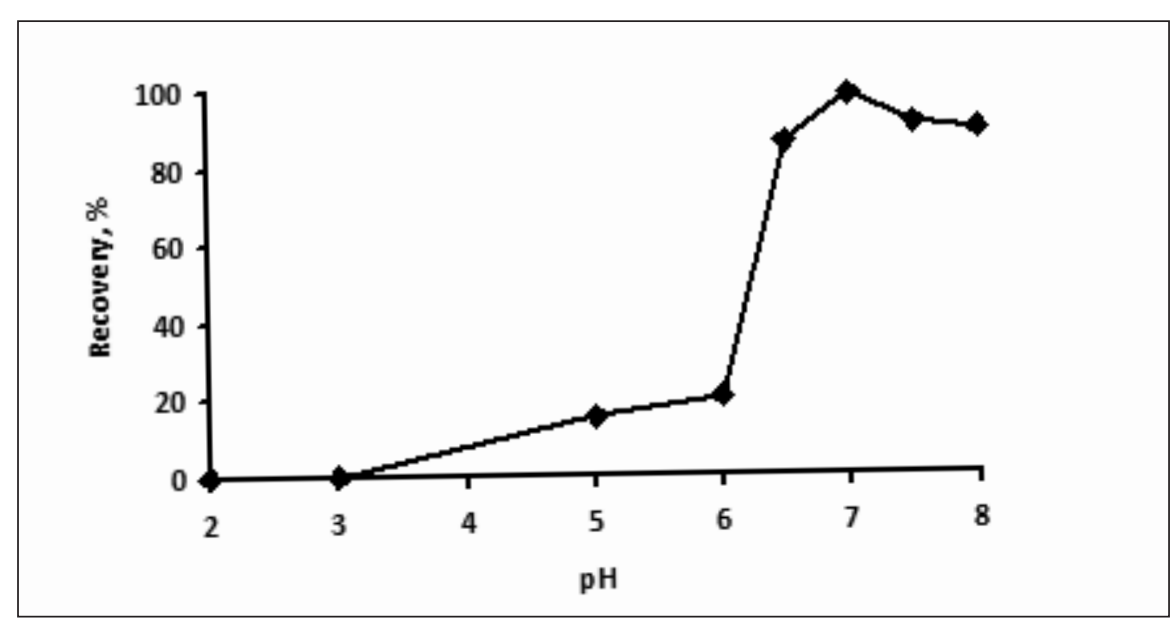

Fig. 1. Extraction percentage of $\mathrm{Pb}(\mathrm{II})$ against $\mathrm{pH}(\mathrm{N}=3)$. 


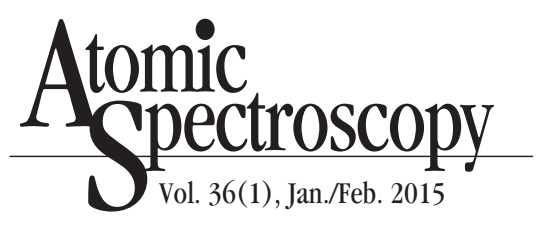

range. The experimental results showed that quantitative recoveries were observed in the flow rate range of $3.0-4.0 \mathrm{~mL} \mathrm{~min}^{-1}$. Above $4.0 \mathrm{~mL} \mathrm{~min}^{-1}$, the recoveries decreased gradually with increasing flow rates. Hence, $4.0 \mathrm{~mL} \mathrm{\textrm {min } ^ { - 1 }}$ was selected for use in further experiments.

\section{Effect of Sample Volume}

In the preconcentration-separation studies for traces of heavy metals, the sample volume is an important factor in order to obtain a high preconcentration factor (40-45). The effect of sample volume on the recoveries was also investigated. Amounts of 20-200 $\mathrm{mL}$ of sample solution were passed through the system at optimum conditions. The results given in Figure 3 show that quantitative recoveries (>95\%) were obtained for analyte sample volumes of $100 \mathrm{~mL}$. For further experiments, $100 \mathrm{~mL}$ of sample solution was adopted for the preconcentration of $\mathrm{Pb}$ (II), the final volume was 5.0 $\mathrm{mL}$ and a preconcentration factor of 20 achieved.

\section{Matrix Effects}

In the atomic absorption spectrometric detection of metal ions, the negative or positive effects of the group IA and IIA metals, the transition metals and some anions, on the signal of the analyte elements are a critical problem (46-51), To overcome this problem, separation of analyte elements from the matrix is necessary. Thus, the influence of these metals and anions were also investigated on the recoveries of $\mathrm{Pb}$ (II) on a cellulose nitrate membrane. The results summarized in Table II show that the ions normally present in water do not interfere under the experimental conditions used. The matrix ions given in Table II were not retained on the cellulose nitrate membrane filter.

\section{Figures of Merit}

The detection limit, evaluated as the concentration corresponding to three times the standard deviation of eight replicate measurements of the blank solution divided by the slope of the analytical curve $\left(3 \mathrm{~S}_{\mathrm{b}} / \mathrm{m}\right)$, was $1.5 \mu \mathrm{g} / \mathrm{L}$. The relative standard deviation of the determinations was less than 5\%.

\section{Accuracy Studies}

To estimate the accuracy of the procedure, different amounts of $\mathrm{Pb}$ (II) were spiked in tap water and mineral water samples, and the resulting solutions were submitted

TABLE II

Effect of Some Ions as Matrix on the Recoveries of $\mathrm{Pb}(\mathrm{III})(\mathrm{N}=3)$

\begin{tabular}{lccc}
\hline Ion & Added As & Concentration $(\mathrm{mg} / \mathrm{L})$ & Recoveries (\%) \\
\hline $\mathrm{Na}^{+}$ & $\mathrm{NaCl}$ & 10000 & $99 \pm 0$ \\
$\mathrm{SO}_{4}^{2-}$ & $\mathrm{Na}_{2} \mathrm{SO}_{4}$ & 1000 & $100 \pm 1$ \\
$\mathrm{Mg}^{2+}$ & $\mathrm{Mg}\left(\mathrm{NO}_{3}\right)_{2} \cdot 6 \mathrm{H}_{2} \mathrm{O}$ & 1000 & $98 \pm 1$ \\
$\mathrm{CO}_{3}^{2-}$ & $\mathrm{Na}_{2} \mathrm{CO}_{3}$ & 2500 & $97 \pm 1$ \\
$\mathrm{Mn}^{+2}$ & $\mathrm{Mn}^{2-}\left(\mathrm{NO}_{3}\right)_{2}$ & 10 & $98 \pm 1$ \\
$\mathrm{Zn}^{2+}$ & $\mathrm{Zn}\left(\mathrm{NO}_{3}\right)_{2} \cdot 6 \mathrm{H}_{2} \mathrm{O}$ & 20 & $94 \pm 2$ \\
$\mathrm{Fe}^{3+}$ & $\mathrm{Fe}\left(\mathrm{NO}_{3}\right)_{3} \cdot 9 \mathrm{H}_{2} \mathrm{O}$ & 20 & $95 \pm 2$ \\
$\mathrm{~K}^{+}$ & $\mathrm{KCl}_{\mathrm{KCl}}$ & 12000 & $94 \pm 1$ \\
$\mathrm{Cl}^{-}$ & $\mathrm{KCl}$ & 12000 & $94 \pm 1$ \\
\hline
\end{tabular}

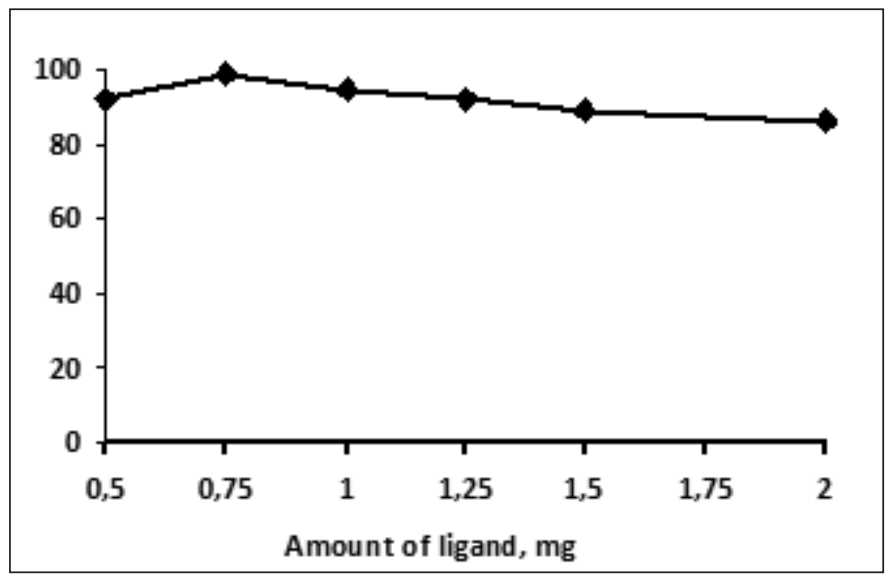

Fig. 2. Extraction percentage of $\mathrm{Pb}(\mathrm{II})$ against amount of Brillant Black BN used ( $N=3)$.

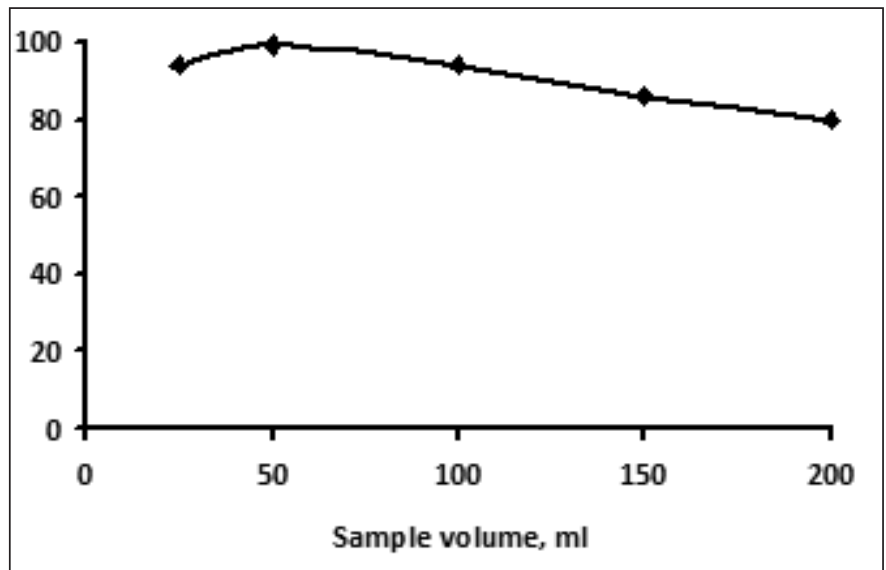

Fig. 3. Effects of sample volume on the recoveries of Pb(II) $(N=3)$. 
to the procedure given in the "Preconcentration Procedure" section. The results summarized in Table III show that good agreement was obtained between the added and measured analyte amounts. The recoveries calculated for the added standards were always quantitative (95\%) which confirms good accuracy of the procedure and no interference from matrix effects.

The accuracy of the proposed procedure was also evaluated by determining the analyte elements in the certified reference materials SPS-WW2 Wastewater and GBW 07424 Soil. The results in Table IV indicate that there is no significant difference between these results and the certified values. The determined values obtained by the proposed membrane filtration method agreed well with the certified values and confirms the suitability of the method for these types of samples.

\section{Application of the Proposed Method to Water and Soil Samples}

The present cellulose nitrate membrane filtration procedure was applied to the determination of lead in a wastewater and three soil samples from Turkey. The results are listed in Table V. The lead level in the wastewater samples from the lead industry was found at $\mu \mathrm{g} / \mathrm{mL}$ levels. This sample was taken before treatment of the wastewater. The level of lead in the analyzed soil samples were found at $\mu \mathrm{g} / \mathrm{g}$ levels.

\section{CONCLUSION}

The present membrane filtration method was successfully applied to the extraction, preconcentration, and determination of lead in water and soil samples by flame atomic absorption spectrometry (FAAS). Lead was quantitatively recovered at $\mathrm{pH} 7.0$ with $0.75 \mathrm{mg}$ of Brillant Black $\mathrm{BN}$ at the flow rate of $4 \mathrm{~mL} / \mathrm{min}^{-1}$. Validation of the mem-
TABLE III

Addition/Recovery Tests for Water Samples ( $\mathrm{N}=3$ )

\begin{tabular}{lccc}
\hline & Added $(\mu \mathrm{g})$ & Found $(\mu \mathrm{g})$ & Recovery $(\%)$ \\
\hline Tap water & 0 & - & BDL \\
& 10 & $9.9 \pm 1$ & 99 \\
\multirow{4}{*}{ Mineral Water } & 0 & $19.8 \pm 0$ & 99 \\
& 10 & - & BDL \\
& 20 & $9.9 \pm 2$ & 99 \\
& $20.5 \pm 1$ & 102 \\
\hline
\end{tabular}

BDL: Below the detection limit.

TABLE IV

Results for Certified Reference Materials

\begin{tabular}{lccc} 
Certified Reference Materials & Certified Value & Obtained Value & Recovery \\
\hline Wastewater Level 2 SPS-WW2 & $0.5 \mu \mathrm{g} / \mathrm{mL}$ & $0.5 \pm 0.0 \mu \mathrm{g} / \mathrm{mL}$ & $100 \%$ \\
GBW 07424 Soil & $22.0 \mu \mathrm{g} / \mathrm{g}$ & $21.5 \pm 0.1 \mu \mathrm{g} / \mathrm{g}$ & $98 \%$ \\
\hline
\end{tabular}

\section{TABLE V}

Application of Presented Membrane Filtration Procedure for the Determination of Lead Levels in Wastewater and Soil Samples $(N=3)$

\begin{tabular}{ll}
\hline Sample & \multicolumn{1}{c}{ Concentration } \\
\hline Wastewater from lead industry & $0.85 \pm 0.02 \mu \mathrm{g} / \mathrm{mL}$ \\
Soil from Kayseri & $22.7 \pm 0.2 \mu \mathrm{g} / \mathrm{g}$ \\
Soil from Urgup & $25.5 \pm 0.4 \mu \mathrm{g} / \mathrm{g}$ \\
Soil from Avanos & $17.1 \pm 0.1 \mu \mathrm{g} / \mathrm{g}$ \\
\hline
\end{tabular}

brane filtration method was checked by using SPS-WW2 Wastewater Level 2 and GBW 07424 Soil certified reference materials. The preconcentration factor obtained was 20 and the detection limit of method was $1.5 \mu \mathrm{g} / \mathrm{l}$. The effects of matrix ions are tolerable.

\section{ACKNOWLEDGMENT}

The authors are grateful for the financial support of the unit for scientific research projects of Erciyes University (Kayseri, Turkey).

Received June 2, 2014. 


\section{REFERENCES}

1. M.G. Frías-Espericueta, F.K.G. Zamora-Sarabia, J.I. Osuna-López, M.D. Muy-Rangel, W. Rubio-Carrasco, and M. Aguilar-Juárez, D. Voltolina, Scientific World J. Article ID 546897 (2014).

2. S. Giri, A.K. Singh, and B.K. Tewary, Environ. Earth Sci. 70, 3381 (2013).

3. A. Duran, M. Tuzen, and M. Soylak, Int. J. Food Sci. Nutr. 59, 581 (2008).

4. K.S. Celik, F. Aydin, M.Z. Duz, I. Aydin, S. Erdogan, O. Akba, and C. Hamamci, At. Spectrosc. 35, 200 (2014).

5. S. Dursun, and S. Onder, Asian J. Chem. 20, 4092 (2008).

6. H. Handt, R. Fernandez, Z. Benzo, C. Gomez, E. Marcano, F. Galarraga, and R. Gonzalez, Atmosfera 21, 335 (2008).

7. M. Tuzen, I. Karaman, D. Citak, and M. Soylak, Food Chem. Toxicol. 47, 1648 (2009).

8. M. Tuzen, E. Sesli, and M. Soylak, Food Control 18, 806 (2007).

9. B.P. Zietz, J. Lass, and R. Suchenwirth, Int. J. Environ Heal. R. 17, 407 (2007).

10. Z. Severoglu, S. Sumer, B. Yalcin, Z. Leblebici, and A. Aksoy, Int. J. Environ. Sci. Te. 10, 295 (2013).

11. S. Saracoglu, M. Tuzen, D. Mendil, M. Soylak, L. Elci, and M. Dogan, B. Environ. Contam. Tox. 73, 264 (2004).

12. J.K.C. Nduka, O.E. Orisakwe, and C.A. Maduawguna, Toxicol. Ind. Health. 24, 539 (2008).

13. M. Tuzen, and M. Soylak, Food Chem. 101, 1378 (2007).

14. L. Elci, M. Soylak, A. Uzun, E. Buyukpatir, and M. Dogan, Fresen. J. Anal. Chem. 368, 358 (2000)

15. S. Dadfarnia, A. M. Haji Shabani, and M. Amirkavei, Turk. J. Chem. 37, 746 (2013).

16. M. Soylak, and N.D. Erdogan, J. Hazard. Mater. 137, 1035 (2006).
17. H. Eskandari, Turk. J. Chem. 36, 631 (2012).

18. M. Soylak, Asian J. Chem. 15, 1780 (2003)

19. C.H. Xiong, X.X. Han, and C.P. Yao, Separ. Sci. Technol. 45, 2368 (2010).

20. M. Soylak, and L. Elci, J. Trace Microprobe. T. 18, 397 (2000).

21. M. Soylak, and M. Dogan, Anal. Lett. 29, 635 (1996).

22. F.A. Silva, C.C.F. Padilha, G.R. de Castro, P.S. Roldan, A.R. de Araujo Nogueira, P.M. Moraes, and P.M. Padilha., Cent. Eur. J. Chem. 9,119 (2011).

23. J. Stas, A. Khuder, and J. Karjou, Appl. Radiat. Isotopes 66, 450 (2008).

24. J. Borkowska-Burnecka, M. Jakubiel, and W. Zyrnicki, Chem. Anal-Warsaw 53, 335 (2008).

25. Y. Xiao, B. Zheng, and K.R. Zhang, Chinese J. Anal. Chem. 35, 1654 (2007).

26. Z. Modarres-Tehrani, M. Askari and J. Mofidi, Asian J. Chem. 19, 5391 (2007)

27. A. Shokrollahi, A. Abbaspour, M. Ghaedi, A.N. Haghighi, A.H. Kianfar, and M. Ranjbar, Talanta 84, 34 (2011).

27. Y. Chen, C.M. Ding, T.Z. Zhou, and D.Y. Qi, Fresenius J. Anal. Chem. 363, 119 (1999).

28. A.U. Karatepe, M. Soylak, and L. Elci, Anal. Lett. 35, 1561 (2002).

29. J. Itoh, M. Komata, and J.P. Susant, Bunseki Kagaku 45, 789 (1996).

30. I. Narin, and M. Soylak, Anal. Chim. Acta. 493, 205 (2003).

31. C. Cpara, S. Hasegawa, and K. Naito, Anal. Sci. 19, 265 (2003).

32. M. Soylak, U. Divrikli, L. Elci, and M. Dogan, Talanta 56, 565 (2002).

33. H.Z. Mousavi, and H. Shirkhanloo, Asian J. Chem. 20, 3633 (2008).

34. M. Soylak, Anal. Lett. 37, 1203 (2004).

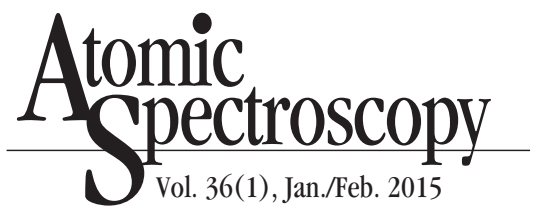

35. H. Tavallali, S. Lalehparvar, A-R. Nekoei, and K. Niknam, J. Chin. Chem. Soc. 58, 199 (2011).

36. H.B. Senturk, A. Gundogdu, V.N. Bulut, C. Duran, M. Soylak, L. Elci, and M. Tufekci, J. Hazard. Mater. 149, 317 (2007).

37. S.N. Podyachev, N.E. Burmakina, V.V. Syakaev, S.N. Sudakova, W.D. Habicher, and A.I. Konovalov, J. Incl. Phenom. Macrocycl. Chem. 71, 161 (2011).

38. K.O. Saygi, M. Tuzen, M. Soylak, and L. Elci, J. Hazard. Mater. 153, 1009 (2008).

39. N.M. El-Ashgar, and I.M. El-Nahhal, J. Disper. Sci. Technol. 27, 915 (2006).

40. M. Tuzen, K.O. Saygi, and M. Soylak, J. Hazard. Mater. 156, 591 (2008).

41. M. Nejati, and Y. Nejad, J. Indian Chem. Soc. 83, 595 (2006).

42. W.Z. Xu, C.X. Li, A.Q. Liu, and Y.S. Yan, Spectrosc. Spect. Anal. 29, 801 (2009).

43. E. Sahmetlioglu, E. Yilmaz, E. Aktas, and M. Soylak, Talanta 119, 447 (2014).

44. S.X. Li, and N.S. Deng, Anal. Bioanal. Chem. 374, 1341 (2002).

45. D.M. Han, W.P. Jia, H.D. Liang, and X.P. Yan, Chinese J. Anal. Chem. 35, 1643 (2007)

46. F.A. Aydin, and M. Soylak, Talanta 72,187 (2007).

47. M. Ince, At. Spectrosc. 35, 223 (2014).

48. M. Soylak, S. Saracoglu, L. Elci, and M. Dogan, Kuwait J. Sci. Eng. 30, 95 (2003).

49. L. Meng, C. Chen and Y. Yang Anal. Lett. 48, 453 (2015).

50. A. Gundogdu, D. Ozdes, C. Duran, V.N. Bulut, M. Soylak, and H.B. Senturk, Chem. Eng. J. 153, 62 (2009).

51. O. M. Kalfa, O. Yalcinkaya, and A. R. Turker, Turk. J. Chem. 36, 885 (2012). 